\title{
Vegetative propagation of Richeria grandis Vahl. by mini-cutting
}

\author{
Cristiane Coelho Moura ${ }^{1}$, Thaís Ribeiro Costa ${ }^{1}$, Luciana Coelho Moura² ${ }^{\oplus}$, Letícia Renata Carvalho ${ }^{3}$, \\ Miranda Titon $^{1} \oplus$, Israel Marinho Pereira ${ }^{1} \oplus$, Evandro Luiz Mendonça Machado ${ }^{1} \oplus$

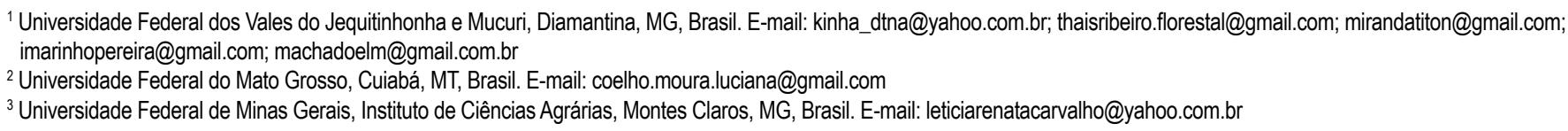

ABSTRACT: Due to deforestation in Gallery Forests, the current environmental law requires their restoration. Using only seminal propagation for native species of this environment has limited the production of seedlings as the seeds of some species often have limiting factors. Richeria grandis Vahl., besides being a characteristic species of this environment, has high value in phytosociological importance; however, it has recalcitrant seeds. In view of this, the objective was to evaluate the rooting of $R$. grandis Vahl. mini-cuttings under the influence of indolebutyric acid (IBA) concentrations. Apical mini-cuttings were prepared with length of $8 \pm 2 \mathrm{~cm}$ and two pairs of leaves with their leaf area reduced by $50 \%$. For rooting, a mixture of $70 \%$ vermiculite and $30 \%$ carbonized rice husk with fertilizer was used as substrate. As treatments, four IBA concentrations were tested: 0; 2,000; 4,000; and $6,000 \mathrm{mg} \mathrm{L}^{-1}$, liquid in solution, for 10 seconds. The rooting of mini-cuttings was conducted in a greenhouse, for a period of 90 days. According to the results, this technique is feasible, since there was $100 \%$ survival and a high percentage of rooting, with the control treatment having the lowest value (85\%). Calluses were found in non-rooted mini-cuttings and, using IBA, there was a tendency to increase the mean number of roots, sprouting percentage and mean sprouts per treatment.

Key words: Gallery Forests; indolebutyric acid; recalcitrant; rooting; seedling production

\section{Propagação vegetativa de Richeria grandis Vahl. por miniestaquia}

RESUMO: Devido ao desmatamento em Matas de Galeria, a lei ambiental vigente exige a restauração destas áreas. Apenas o uso da propagação seminal para espécies nativas deste ambiente tem limitado a produção de mudas, visto que sementes de algumas espécies muitas vezes possuem algum fator limitante. Richeria grandis Vahl. além de ser uma espécie característica deste ambiente, apresenta alto valor de importância fitossociológica, no entanto, suas sementes são recalcitrantes. Diante disto, objetivou-se avaliar o enraizamento de miniestacas de $R$. grandis Vahl. sob influência de concentrações de ácido indolbutírico (AIB). As miniestacas apicais foram preparadas com comprimento de $8 \pm 2 \mathrm{~cm}$ e dois pares de folhas reduzidas em $50 \%$ a área foliar. Para o enraizamento, foi utilizado como substrato, a mistura de $70 \%$ de vermiculita e $30 \%$ de casca de arroz carbonizada com adição de fertilizante. Como tratamentos, foram testadas quatro concentrações de AIB: 0; 2.000, 4.000 e $6.000 \mathrm{mg} \mathrm{L}^{-1}$, via líquida, durante 10 segundos. 0 processo de enraizamento das miniestacas foi conduzido em casa de vegetação, por um período de 90 dias. De acordo com os resultados, esta técnica é viável, uma vez que houve $100 \%$ de sobrevivência e alta porcentagem de enraizamento, sendo o tratamento controle com o menor valor (85\%). Observou-se a presença de calos em miniestacas não enraizadas e, com o uso de AIB, houve tendência de aumento do número médio de raízes, porcentagem de brotação e média de brotos por tratamento.

Palavras-chave: Matas de Galeria; ácido indolbutírico; recalcitrante; enraizamento; produção de mudas 


\section{Introduction}

Tropical forests have already lost much of their original covered area due to the great exploratory process over the years, in especially those that are along springs and watercourses, such as the Gallery Forests (Silva, 2015). This happens even though these said forests are protected by Brazilian legislation such as the Permanent Preservation Areas - APP (initials in Portuguese) (Law No. 12,651 of 25/05/2012; amended by Law No. 12,727 of $17 / 10 / 2012$; CONAMA Resolutions 302/02 and 303/02).

The Gallery Forests have high genetic diversity of plant species, with rare species predominating over few conspicuous species, well adapted to this stress environment (Dietzsch et al., 2006). In addition to this, they also stand out for contributing to the maintenance, protection and quality of water resources and assist the conservation of wild fauna acting as ecological corridors (Oliveira et al., 2015; Nogueira, 2016).

Regarding the high deforestation rate of these APPs, the Federal law ensure their control and inspection, establishing recovery goals and guidelines through the restoration of these degraded areas. One of the restoration techniques used is the planting of native seedlings occurring in the areas to be restored (Martins, 2015), and for that matter, bettering the propagation techniques for native species will contribute in advancing the forestry in several different sectors, including the restoration of degraded areas and environmental preservation (Fonseca, 2016).

However, most studies concerning the propagation of native forest species are related to the sexual propagation, yet its use has limited the seedlings commercial production, since the seeds of most woody species have some limiting factors (Ferriani et al., 2010), mainly for recalcitrant and late secondary species. It is worth mentioning that the species that produce desiccation-sensitive seeds correspond to from 7.5 to $19.6 \%$ of the plant species in the world, and in tropical forests, which includes the Gallery Forests, the contribution to this percentage is expressive (Wyse \& Dickie, 2017).

Despite the diversity of woody species in the Brazilian flora, there are few studies with vegetative propagation (Hernández et al., 2013; Fonseca, 2016). Vegetative propagation techniques, including the mini-cuttings, are a promising alternative for overcoming any difficulties in seedling production (Oliveira \& Ribeiro, 2013), and are one of the main processes for producing good quality seedlings (Oliveira \& Ribeiro, 2013).

The species studied was the Richeria grandis Vahl. (Phyllanthaceae), an evergreen tree, non-pioneer, widely geographical distributed and having a unique environmental specificity (Rabinowitz, 1981). Considered as one of the most representative species of riparian environments, the species is characterized by hydromorphic and dystrophic soils (Costa, 2017), mainly by Ciliary and Gallery Forests (Cerqueira et al. 2016; Costa, 2017; Moura, 2017). It has morphophysiological adaptations to withstand the physical conditions and low oxygenation of the soil in these said locations (Bambi et al.,
2016), and is responsible for contributing of over $50 \%$ of the litter biomass, thus acting as determining for the stability of these ecosystems (Rezende et al., 2017; Calderón et al. 2019). Furthermore, it is an accumulator species of $\mathrm{Al}^{3+}$ (Cuenca et al., 1991), a metal regarded as toxic, when in high concentrations, to both plant growth and development.

Bearing this in mind, the need of incorporating the said species in programs for restoring this phytocenosis is justified. However, its seeds, in addition to their recalcitrant nature, which means losing their total viability only in a few days of storage, are also not produced annually (Moura, 2017).

In light of the foregoing, the objective of this study was to evaluate the viability of the vegetative propagation of Richeria grandis Vahl. mini-cuttings under the influence of different indolbutyric acid (IBA) concentrations.

\section{Materials and Methods}

The study was conducted in a greenhouse (covered with a $150-\mu$-thick plastic film and a $50 \%$ shading screen) located at the Integrated Center of Forest Species Propagation CIPEF) of the Forestry Department, at the Federal University of Vales do Jequitinhonha e Mucuri, Diamantina, Minas Gerais, Brazil (18 $12^{\prime} \mathrm{S} ; 43^{\circ} 34^{\prime} \mathrm{W}$ and altitude of $1370 \mathrm{~m}$ ).

The used plant material was from 80 young seedlings of Richeria grandis Vahl. brought in by Oliveira (2014) in 2012, from areas cleared for vegetation suppression in remnants of Atlantic Forest destined for implementing mining areas, tailings dam and other facilities belonging to the Anglo American mining company, in the municipality of Conceição do Mato Dentro, MG. These seedlings were transplanted into $10 \times 15 \times 0.20 \mathrm{~cm}$ plastic bags with capacity for $0.03 \mathrm{dm}^{3}$, containing substrate composed of $70 \%$ subsoil, $15 \%$ tanned manure, $15 \%$ Bioplant $^{\circledR}$ and $7 \mathrm{~g} \mathrm{~L}^{-1}$ of Osmocote ${ }^{\circledR}$ in the N-P-K proportion (15-9-12), slow releasing from 5 to 6 months (Oliveira, 2014). They were allocated in a semi-acclimatized greenhouse for 210 days in order to develop and recover from the stress caused by the transport and, later, to the hardening area, remaining there until the present study.

The apical mini-cuttings were removed from these seedlings after 4 years of being taken from the field, at the end of the rainy season (April/2016), and prepared with length of $8 \pm 2 \mathrm{~cm}$ in height and $5 \pm 1 \mathrm{~mm}$ in diameter, keeping the minimum of two pairs of leaves reduced to half their original size. In order to maintain the conditions of vigor and turgidity of the vegetative material, immediately after collection, the mini-cuttings were packed in Styrofoam boxes with water, with irrigation held by means of a manual spray, in intervals of less than 10 minutes until the plantation.

As for the rooting, hard conical plastic tubes with capacity for $180 \mathrm{~cm}^{3}$ were used, containing as substrate the mixture of $70 \%$ vermiculite and $30 \%$ rice husk ash with the addition of fertilizer at $5 \mathrm{~g} \mathrm{~L}^{-1}$ of the Osmocote ${ }^{\circledR}$ controlled-release formulation at the N-P-K proportion (15-9-12). The minicuttings were placed on the substrate, paying attention to its centering, straightness, depth $(2 \mathrm{~cm})$ and firmness. 
As treatments, four indolbutyric acid (IBA) concentrations were tested: $0 ; 2,000 ; 4,000 ;$ and $6,000 \mathrm{mg} \mathrm{L}^{-1}$. The IBA solution was prepared by dissolving the acid in sodium hydroxide $(\mathrm{NaOH})$ and then diluting it in distilled water. The mini-cutting bases were immersed in the IBA solution for 10 seconds.

The mini-cuttings rooting process was performed in a semi-acclimated greenhouse, for a period of 90 days, with monitored environment conditions, aiming at obtaining a temperature of around $28{ }^{\circ} \mathrm{C}$ and relative humidity of over $80 \%$. The luminosity inside was reduced by $50 \%$ of natural light due to the shading at the top of the structure.

At 90 days, the percentage of survival (\%) and rooting (\%), mean number of roots (NR) (total number of roots ( $\geq 2 \mathrm{~mm}$ in length) (TNR) by the number of rooted mini-cuttings (RM), and the mean root length (RL) (total root length (TRL) (sum of the length values of each root) by the mean number of roots (NR)). The percentage of callogenesis (\%) and the mean number of calluses (NC) (total number of calluses (TNC) were determined by the number of hardened cuttings (C)), when cell differentiation occurred at the base of the mini-cutting. It was also evaluated the percentage of shoots emitted (\%), the mean number of shoots (NS) (total number of shoots (TNS) by the number of mini-cuttings that sprouted (S) and the increase in height $(\mathrm{IH})$ and diameter of the mini-cuttings (ID).

The randomized blocks experimental design was used, consisting of four treatments (IBA concentrations), in four blocks with five cuttings per plot (totaling 80 mini-cuttings). For statistical analysis, the assumptions of normality (ShapiroWilk test) and homoscedasticity (Bartlett test) were calculated and tested, at a level of $5 \%$ significance. The variances were compared by using the $\mathrm{F}$ test at the $5 \%$ significance level. Regression analyzes were held using the treatment means. For all analyzes, the statistical software R ( R Development Core Team, 2020) and the package "ExpDes.pt" (Ferreira et al., 2018) were employed. As for the results that did not show any significant differences $(p>0.05)$, descriptive analysis by graphs means was used.

\section{Results}

For all analyzed variables, the statistical assumptions were met $(p>0.05)$, with residuals and variance of normal and homogeneous residuals, respectively. However, the analyzes of variance from the regressions were not significant $(p>$ $0.05)$ for the following variables: rooting (\%), root length (RL), number of shoots (NS), increase in height (IH) and diameter (ID). To that end, the data were analyzed descriptively from the means, standard errors of the means and coefficients of variation, and displayed in bar graphs.

All mini-cuttings survived (100\%) keeping their initial leaves for 90 days (the entire experimental period), having a high rooting percentage, with the control treatment retaining the lowest mean value (85\%) (Figure $1 \mathrm{~A}$ ), with a coefficient data variation (CV) of $12.15 \%$. The mean root length ( $\mathrm{RL}$ ) ranged from $13.19 \mathrm{~cm}$, for the control, to $19.89 \mathrm{~cm}$, for the treatment that had 2000 $\mathrm{mg} \mathrm{L}^{-1}$ of IBA added to it ( $C V=20.47 \%$ ) (Figure $\left.1 \mathrm{~B}\right)$.
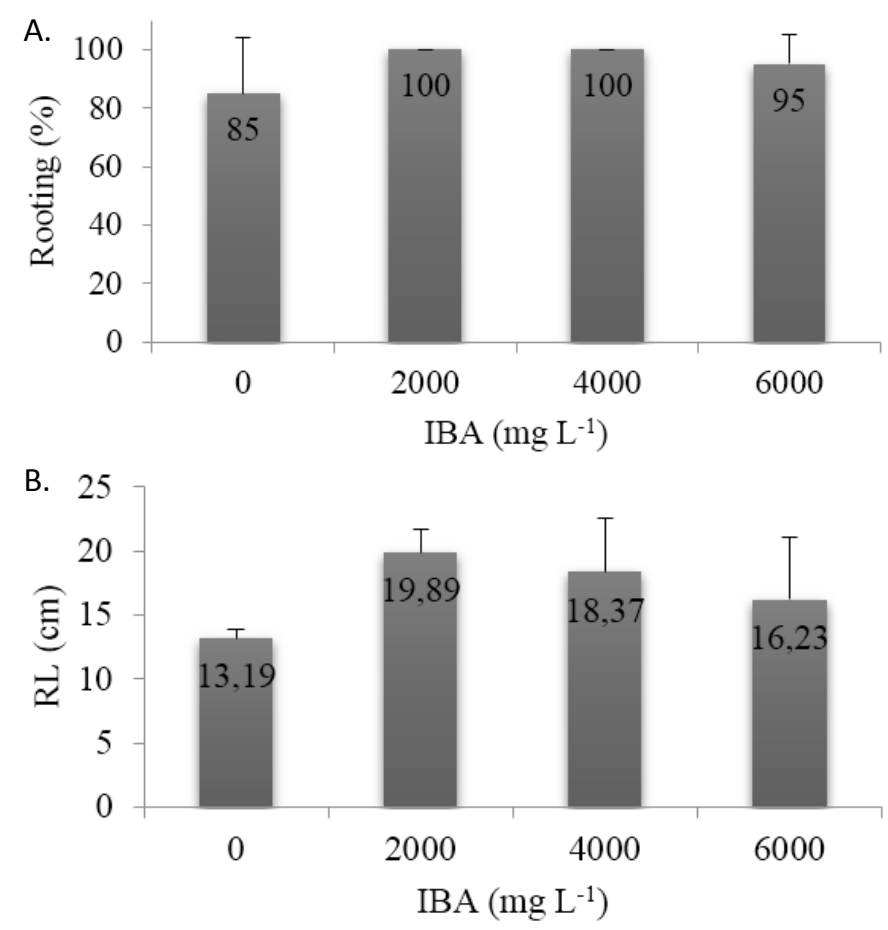

Figure 1. (A) Relation between the concentration of indolbutyric acid (IBA) and the mean rooting rate (\%) of mini-cuttings of Richeria grandis Vahl. (B) Relation between the concentration of indolbutyric acid (IBA) and the mean root length (RL) of Richeria grandis Vahl. mini-cuttings in a greenhouse at 90 days. Lines above the bars indicate the standard error of the mean.

Significant differences $(p<0.05)$ found by the $F$ test between IBA concentrations for were regarding the following characteristics: mean number of roots (NR), percentage of callogenesis, mean number of calluses (NC), and percentage of sprouts.

There is a tendency to increase the mean number of roots (NR) as the concentration of the plant regulator rises (Figure 2), which is explained by a simple linear regression with the coefficient of variation of $15.77 \%$.

Figure 3 illustrates these results; where the mini-cuttings treated with 2000, 4000 and $6000 \mathrm{mg} \mathrm{L}^{-1}$ IBA (Figure 3A, D) have

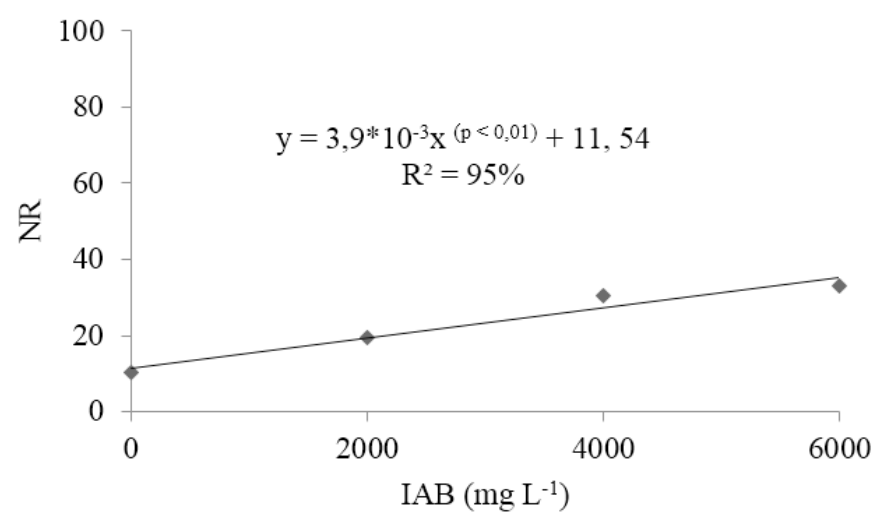

Figure 2. Relation between the concentration of indolbutyric acid (IBA) and the mean number of roots (NR) of Richeria grandis Vahl. rooted mini-cuttings in a greenhouse at 90 days. 

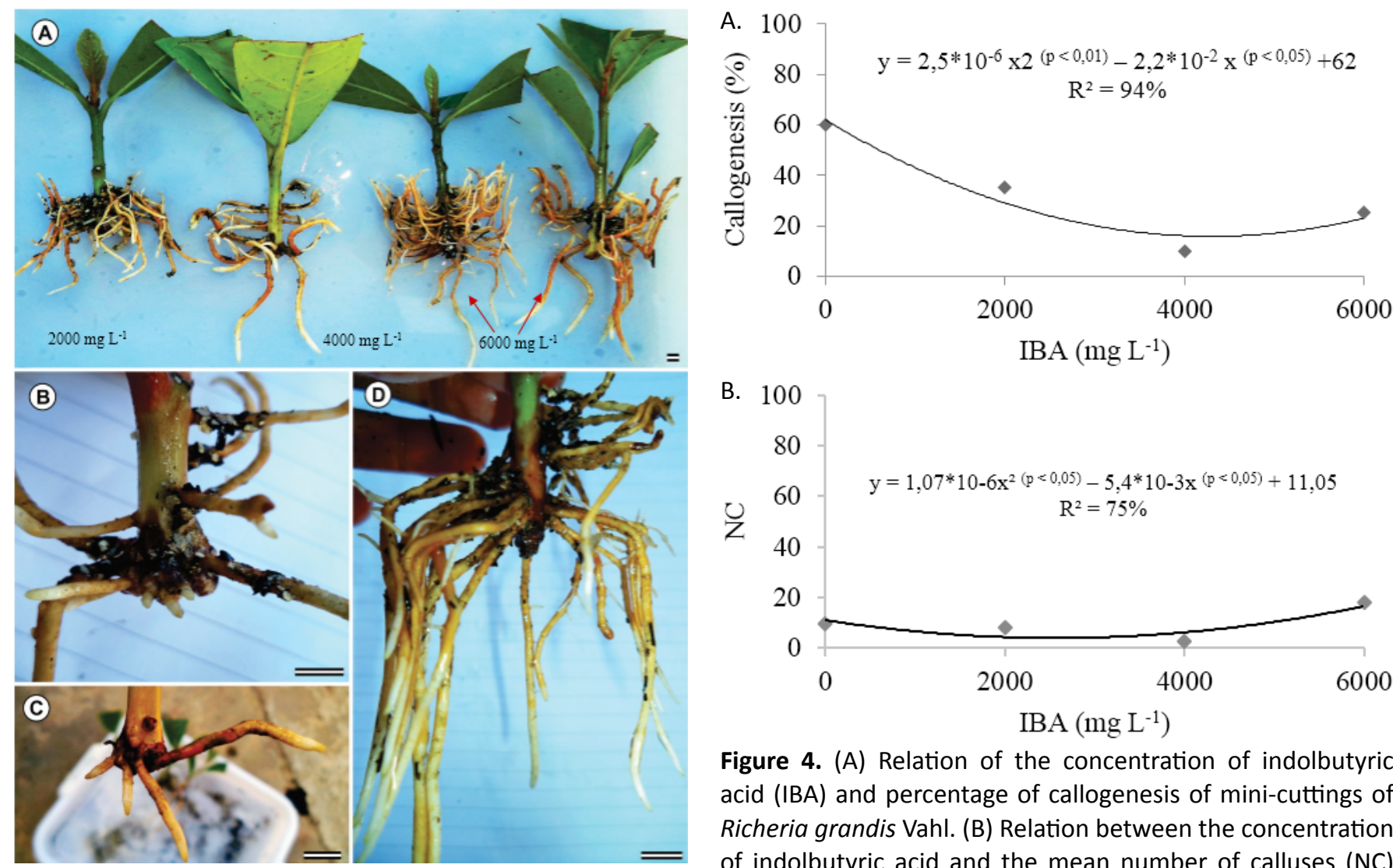

Figure 4. (A) Relation of the concentration of indolbutyric acid (IBA) and percentage of callogenesis of mini-cuttings of Richeria grandis Vahl. (B) Relation between the concentration of indolbutyric acid and the mean number of calluses (NC) Figure 3. Rooting of Richeria grandis Vahl. mini-cuttings in a greenhouse at 90 days, in which: (A) Mini-cuttings subjected to the indolbutyric acid concentrations of 2000, 4000 and $6000 \mathrm{mg} \mathrm{L}^{-1}$; (B) (C) Rooted mini-cuttings without addition of indolbutyric acid and (D) Rooted mini-cuttings with addition of $4000 \mathrm{mg} . \mathrm{L}^{-1}$ of indolbutyric acid. The lines in the figure are equivalent to $1 \mathrm{~cm}$.

a higher mean number of roots than the control treatment (Figure 3B, C).

The calluses formation occurred at the base of the minicuttings in all treatments (Figure 5B-D). The treatments that had a rooting rate below $100 \%$ ( 0 and $6000 \mathrm{mg} \mathrm{L}^{-1}$ ), had their highest callogenesis percentage $(p<0.05)$ (Figure $4 A)$. The control treatment demonstrated a higher callogenesis percentage, with it gradually decreasing in the concentrations of 2000 and $4000 \mathrm{mg} \mathrm{L}^{-1}$, and increasing once again in the IBA concentration of $6000 \mathrm{mg} \mathrm{L}^{-1}$, thus composing a quadratic regression with a variation coefficient of $47 \%$ (Figure $4 \mathrm{~A}$ ).

As observed for the percentage of callogenesis, the mean number of calluses per treatment $(p<0.05)(C V=58.78 \%)$ demonstrated a quadratic trend (Figure 4B). However, it is worth emphasizing that for the treatment with concentration of $6000 \mathrm{mg} \mathrm{L}^{-1}$, the mean number of calluses was higher in relation to the other dosages. This can be explained by the fact that even the percentage of mini-cuttings that had calluses occurring in this concentration was lower than the control treatment, so the $6000 \mathrm{mg} \mathrm{L}^{-1}$ concentration had a higher number of calluses per callused mini-cuttings, when compared to the other treatments. present in the base of Richeria grandis Vahl. cuttings in a greenhouse at 90 days.

Furthermore, shoots were found in rooted mini-cuttings (Figure 5C, E). Regarding the sprouting percentage $(p<0.05)$ and the number of sprouts, the treatment with the highest IBA concentration also had the highest mean (Figure 6A). There is an increase in sprouts (\%) as the IBA concentration rises $(p<0.05)$ (Figure 6A), explained by a linear regression with a coefficient of variation of $51.8 \%$, and means varying between 0.75 and 2.67 sprouts per treatment $(p>0.05)(C V=$ $63.24 \%)$, for the control and the treatment with concentration of $6000 \mathrm{mg} \mathrm{L}^{-1}$, respectively (Figure 6B).

In general, an increase in height $(\mathrm{IH})$ and diameter (ID) is observed for all mini-cuttings, even though it is not statistically significant $(p>0.05)$. The control resulted in the lowest height growth and the largest diameter growth (Figure 7), whereas the mini-cuttings treated with $4000 \mathrm{mg} \mathrm{L}^{-1}$ of IBA had the opposite results from the control, that is, a greater growth in height and a smaller growth in diameter (Figure 7). Even so, standard errors of high means are observed for both characteristics, with a variation coefficient of $128.89 \%$ and $131.44 \%$ for height and diameter growths, respectively.

\section{Discussion}

The survival of all mini-cuttings and the high rooting percentage obtained in this experiment was very expressive, even with the absence of IBA plant regulator, since according to Xavier et al. (2013), rooting is one of the most critical aspects of the propagation. 


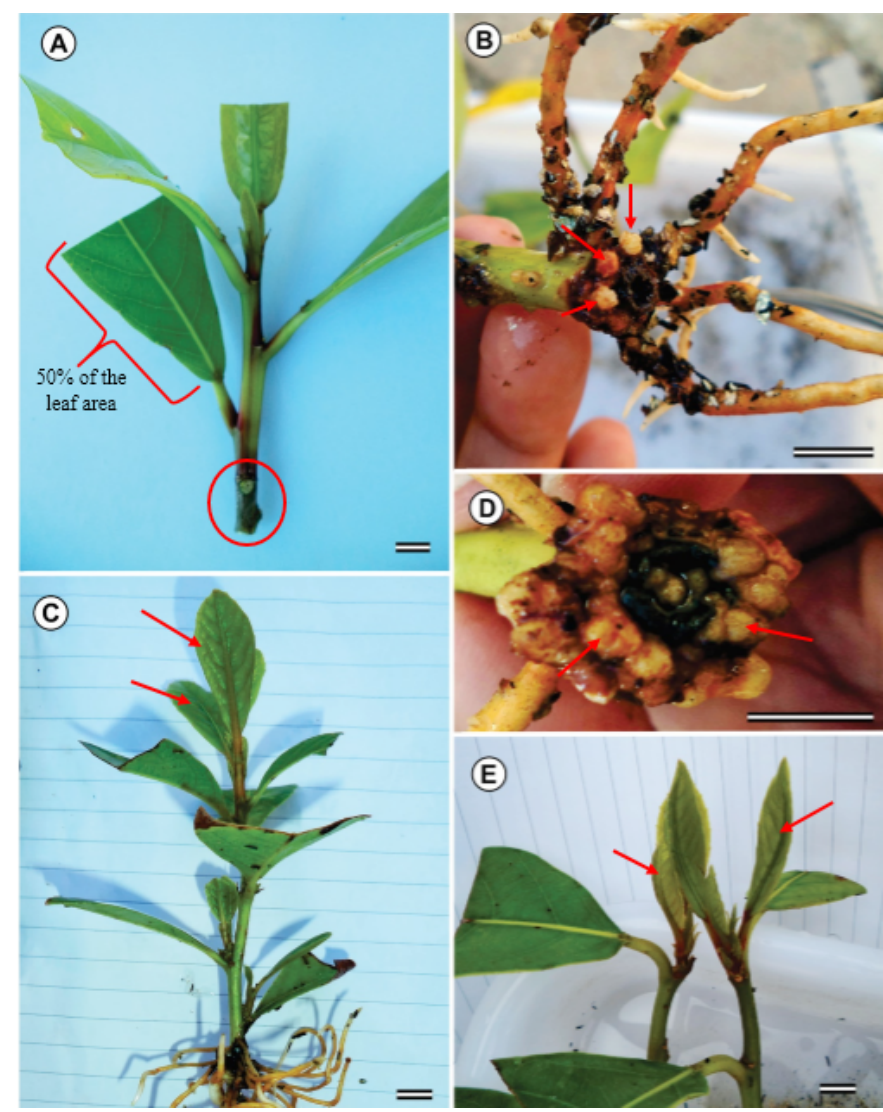

Figure 5. (A) Preparation of Richeria grandis Vahl. mini-cuttings to be subjected to the treatments, at time 0; (B) (D) Presence of calluses on the base of Richeria grandis Vahl. cuttings subjected to different indolbutyric acid concentrations, in a greenhouse at 90 days; (C) (E) Presence of sprouting in Richeria grandis Vahl. mini-cuttings subjected to the $6000 \mathrm{mg}$ $\mathrm{L}^{-1}$ concentration in a greenhouse at 90 days. The lines in the figure are equivalent to $1 \mathrm{~cm}$.

Oliveira (2003) also found positive results for $R$. grandis rooting in cuttings collected from stock trees, located in Gallery Forests, at different periods of the year, which had the ability to emit adventitious roots regardless of the IBA application, although having a lower percentage than the one found in this present study. Other authors have also obtained positive results on the rooting of cuttings without adding IBA for some

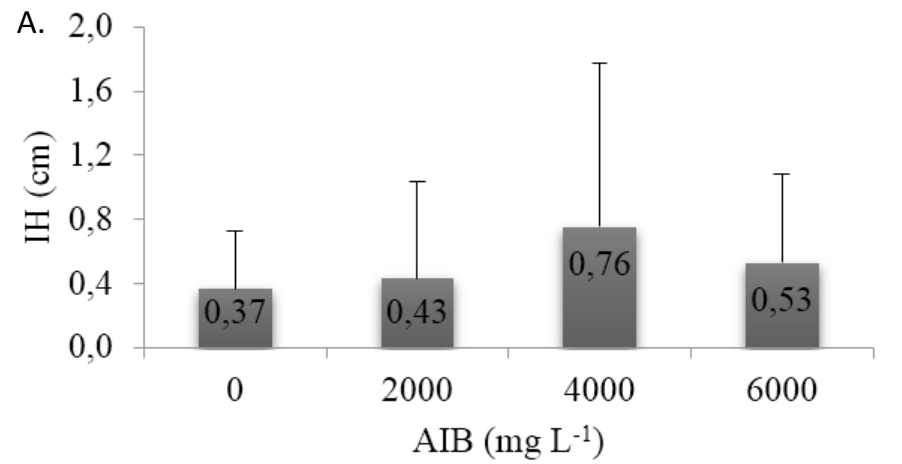

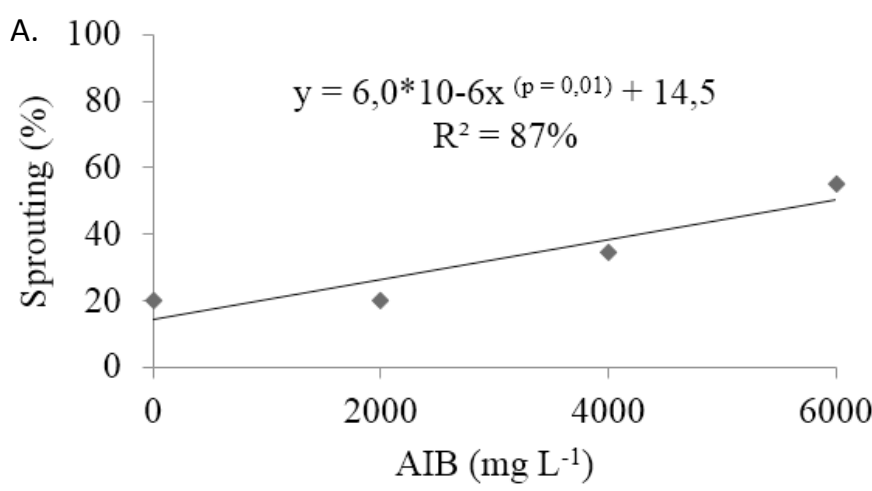

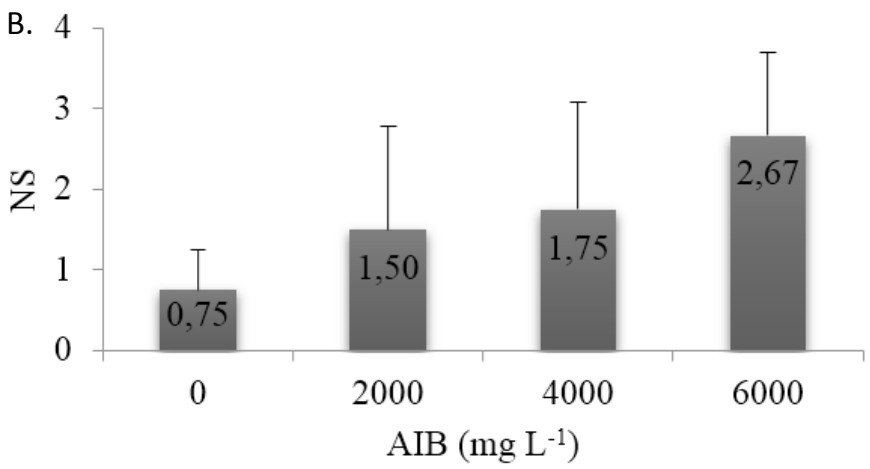

Figure 6. (A) Relation of the concentration of indolbutyric acid (IBA) and percentage of sprouting of Richeria grandis Vahl. mini-cuttings (B) Relation between the concentration of indolbutyric acid and the mean number of sprouts (NB) present in Richeria grandis Vahl. mini-cuttings, in a greenhouse at 90 days. Lines above the bars indicate the standard error of the mean.

species from the Phyllanthaceae family such as the Phyllanthus sellowianus (Klotzch) Mull. Arg. (Monteiro et al., 2010) and Phyllanthus macrocalyx Mull. Arg. (Kumar et al., 2016).

Studies on the vegetative propagation of other native species that are typical of Gallery Forests such as Inga laurina (Sw.) Willd., Protium almecega Marchand, Pseudolmedia laevigata Trécul, Xylopia emarginata Mart. (Oliveira, 2003), Piper arboreum Aubl. (Oliveira, 2003; Rios \& Ribeiro, 2014) and Euplassa inaequalis (Pohl) Engl. (Oliveira, 2003; Oliveira \& Ribeiro, 2013), also demonstrate no need for treatment with IBA in the adventitious rooting of cuttings.

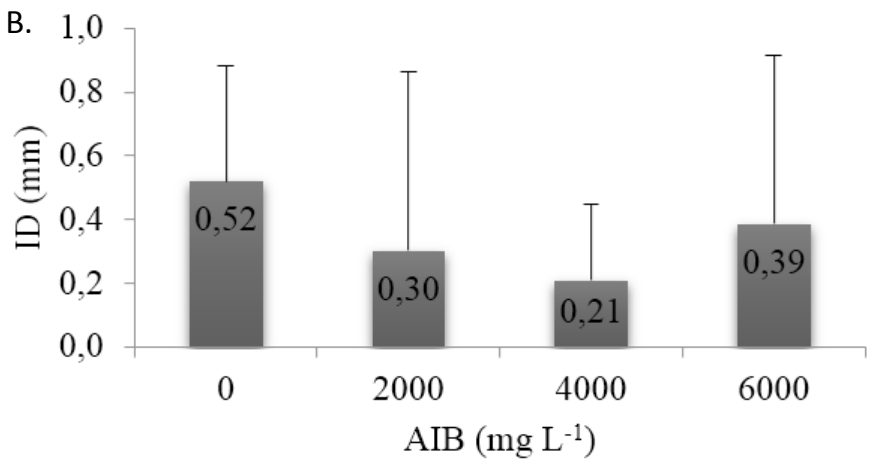

Figure 7. (A) Relation between the concentration of indolbutyric acid and the height increase (IH) of Richeria grandis Vahl. minicuttings (B) Relation between the concentration of indolbutyric acid and the increase in diameter (ID) of Richeria grandis Vahl. mini-cuttings, in a greenhouse at 90 days. Lines above the bars indicate the standard error of the mean. 
Using propagation material from juvenile seedlings may have favored the rooting, even in the control treatment, as it is a less lignified material with a lower degree of physiological maturation and close to the active growing region, it becomes a more vegetative material responsive to adventitious rooting, often dismissing the application of exogenous auxin (Xavier et al., 2013).

According to the classification by Hartmann et al. (2011), there are species that fall into the category of plants that already possesses all essential endogenous components to initiate the rooting, including auxins. The present result indicates that $R$. grandis is classified within this said category and, thus, it can be classified as a species of easy rooting, since the cuttings had adequate levels of endogenous auxins to stimulate the division of the cambium cells and promote the appearance of adventitious roots in stem cuttings. The auxin naturally formed in these plants with active growth (apical meristem, axillary buds and young leaves), are transported, through the phloem, to the base of the cuttings and, together with other substances and appropriate environmental conditions, are responsible for forming the root system (Hartmann et al., 2011). Oliveira (2003) also points out that, possibly, the endogenous auxins in $R$. grandis increase the rooting capacity of the species, since in their study the control group (no IBA application) had $40 \%$ of rooting percentage for cuttings collected at the early dry season.

It is known that the presence of the initial leaves assists rooting and ensures the cutting survival in many plant species, since the stimulus of the cambium activity and cell differentiation starting with the root formation occurs through the carbohydrates production via photosynthesis (Fachinello et al., 2005). Furthermore, it also supply endogenous auxins and other important substances that influence the root formation and the emission of sprouts (Hartmann et al., 2011).

Oliveira \& Dorigon (2016) concluded in their study that cuttings that retain the initial leaves of the treatment positively influence survival and rooting. The presence of leaves, then, can be associated with the favorable results for the survival and rooting of $R$. grandis, in addition to exogenous factors such as temperature, incidence of light, quality of the substrate, favorable nutritional and water conditions, absence of injuries (Xavier et al., 2013), and absence of oxidative reactions at the base of the piles, which may also have favored the good results.

However, it was observed that both the mean root length and the mean number of roots were smaller and more uneven for the control treatment, while for the ones that had addition of exogenous auxins, it resulted in higher values and little variation (Figure 3). Oliveira (2003) also noted that even though there were no statistical differences in their results, for treatments with IBA application on $R$. grandis cuttings, there were higher rooting values.

This result can be explained according to Hartmann et al. (2011) and Xavier et al. (2013), since auxin applications provide a higher percentage, speed, quality and rooting uniformity. Using IBA is widely recommended and practiced, due to its stability to photodegradation, low toxicity and mobility, and high chemical stability (Hartmann et al., 2011). Kumar et al. observed rooting results of cuttings with IBA addition (2016) studying Phyllanthus macrocalyx Mull. Arg., a species part of the same family as $R$. grandis.

There are also some species characteristic of Gallery Forests that are only able to emit adventitious roots from cuttings and with using IBA, represented by Cariniana estrellensis (Raddi) Kuntze (Hernández et al., 2013), Copaifera langsdorffii Undo (Rios \& Ribeiro, 2014), llex paraguariensis A.St.-Hil. (Santin et al., 2015) and by Calophyllum brasiliense Cambess. (Oliveira, 2003; Rios \& Ribeiro, 2014; Silveira et al., 2016).

According to Hartmann et al. (2011), root formation in some species is preceded by appearance of calluses at the base of the cuttings, serving to indicate the favoring of the rooting conditions. Therefore, the presence of these calluses, mainly in the cuttings of the control treatment of this study, may be an indication that, if the cuttings remained for a longer period in the greenhouse, the percentage of rooting and the number of roots could be increased, not differing from other treatments.

The difference in sprouting percentage and the number of sprouts from treatments that had a significant improvement in rhizogenesis in relation to the control, may be related to a secondary action by the plant regulator (Kotz et al., 2011), mainly regarding the increase in the number of roots, which caused an increase in the absorption of nutrients in the substrate (Taiz \& Zeiger, 2013), favoring sprout emission.

The higher height growth in these treatments, even if not statistically proven, besides being related to the greater amount of roots and sprouts, due to the increase in the nutrient absorption and higher photosynthetic rates, may also be related to the other auxin action, which composes the phytohormones group related to cell expansion and stretching (Gastl Filho et al., 2019). Thus, mini-cuttings subjected to exogenous plant regulator attained greater heights when compared to the control group.

Therefore, when comparing the species under study with other forest species that occur in Gallery Forests, the asexually produced $R$. grandis seedlings for programs of restoration of these forests is very advantageous. This is because some studied species, typical to these areas, do not take root, or do so only with presence of plant regulators, such as the following: Tibouchina stenocarpa (Schrank \& Mart. ex DC.) Cogn. (Rios \& Ribeiro, 2014), Virola sebifera Aubl., Myrcia sellowiana O.Berg, Hirtella gracilipes (Hook.f.) Prance (Oliveira, 2003) which are unable to spread asexually; Maclura tinctoria (L.) D. Don ex Steud., Salacia elliptica (Mart. Ex Schult.) G. Don, Emmotum nitens (Benth.) Miers (Oliveira, 2003) and Bauhinia rufa (Bong.) Steud. (Rios \& Ribeiro, 2014) which take root only when adding some concentrations of exogenous auxins.

Although asexual propagation can compromise genetic diversity in the environment (Oliveira \& Ribeiro, 2013), the minicutting technique (propagules from rejuvenated material) is an alternative in overcoming difficulties in propagating native 
species, and can be used for commercial purposes as well as assisting the formation of recovering seedlings, via restoration (Oliveira \& Ribeiro, 2013), of the Gallery Forests, since the seeds of some species are recalcitrant (Oliveira, 2003).

\section{Conclusions}

Richeria grandis proved to be an easy-rooting species.

All mini-cuttings survived regardless of the application of the IBA plant regulator.

The vegetative propagation technique (adventitious rooting) for $R$. grandis, by mini-cutting, without adding indolbutyric acid (IBA), is feasible.

Using IBA caused a tendency of increasing the mean number of adventitious roots and the sprouting percentage.

\section{Acknowledgements}

This study was conducted with the support of the Coordination for the Improvement of Higher Education Personnel - Brazil (CAPES) - Financing Code 001, and the Anglo American Brazil company.

\section{Literature Cited}

Bambi, P.; Rezende, R.S.; Cruz, T.M.S.; Batista, J.E.A.; Miranda, F.G.G.; Santos, L.V.; Gonçalves Júnior, J.F. Diversidade da flora fanerogâmica de três matas de galeria no bioma cerrado. Heringeriana, v.10, n.2, p.147-167, 2016. http://revistas. jardimbotanico.ibict.br/index.php/heringeriana/article/ view/224. 20 May 2020.

Calderón, C.D.C.; Rezende, R.S.; Calor, A.R.; Dahora, J.S.; Aragão, L.N.; Guedes, M.L.; Medeiros, A.O. Temporal dynamics of organic matter, hyphomycetes and invertebrate communities in a brazilian savanna stream. Community Ecology, v.20, n.3, p.301313, 2019. https://doi.org/10.1556/168.2019.20.3.10.

Cerqueira, C.L.; Lisboa, G.S.; Stepka, T.F.; Lopes, M.S.; Vendruscolo, D.G.S.; França, L.C.J.; Miranda, D.L.C. Floristic, phytosociology and diametric distribution of a fragmente of ciliary área in a cerrado área in Piauí, Brazil. Nativa, v.4, n.6, p.360-367, 2016. https://doi.org/10.14583/2318-7670.v04n06a03.

Costa, T.R. Análise florístico-estrutural, relação vegetação-ambiente e transição floresta-campo das matas de galeria do Parque Nacional das Sempre-Vivas (PNSV), MG. Diamantina: Universidade Federal dos Vales do Jequitinhonha e Mucuri, 2017. 135p. Dissertação Mestrado. http://acervo.ufvjm.edu.br/jspui/handle/1/1744. 13 May 2020.

Cuenca, G.; Herrera, R.; Merida, T. Distribution of aluminum in accumulator plants by $\mathrm{x}$-ray-microanalysis in Richeria grandis Vahl leaves from a cloud forest in Venezuela. Plant Cell Environ, v.14, n.4, p.437-441,1991.https://doi.org/10.1111/j.1365-3040.1991. tb00954.x.

Dietzsch, L.; Rezende, A.V.; Pinto, J.R.R.; Pereira, B.A.S. Caracterização da flora arbórea de dois fragmentos de mata de galeria do Parque Canjerana, DF. Cerne, v.12, n.3, p.201-210, 2006. http:// www.cerne.ufla.br/site/index.php/CERNE/article/view/634/534. 20 May 2020.
Fachinello, J.C.; Hoffmann, A.; Nachtigal, J.C. Propagação de plantas frutíferas. Brasília: Embrapa Informação Tecnológica, 2005. 221 p.

Ferreira, E.B.; Cavalcanti, P.P.; Nogueira, D.A. ExpDes: Experimental Designs Pacakge. R package version 1.2.0. 2018. https://cran.rproject.org/web/packages/ExpDes.pt/index.html. 18 May 2020.

Ferriani, A.P.; Zuffellato-Ribas, K.C.; Wendling, I. Miniestaquia aplicada a espécies florestais. Revista Agro@mbiente On-line, v.4, n.2, p.102-109, 2010. https://doi.org/10.18227/1982-8470ragro. v4i2.363.

Flora do Brasil 2020 em construção. Jardim Botânico do Rio de Janeiro. http://floradobrasil.jbrj.gov.br/reflora/floradobrasil/ FB31387. 20 May 2020.

Fonseca, R.M.C. Propagação de Guazuma ulmifolia Lam. por miniestaquia. Cuiabá: Universidade Federal de Mato Grosso, 2016. 65p. Dissertação Mestrado. https://www1.ufmt.br/ufmt/ unidade/userfiles/publicacoes/04c28226141c11b10df0adb30aff 095d.pdf. 13 May 2020.

Gastl Filho, J.; Carvalho, V.; Rezende, A.S.; Almeida, A.M.M.; Nascimento, V.A.; Bonetti, L.L.S. Efeito do extrato de tiririca no enraizamento e desenvolvimento inicial da Amoreira-Preta. Revista Inova Ciência \& Tecnologia, v.5, n.1, p.18-24, 2019. http://periodicos.iftm.edu.br/index.php/inova/article/view/690. 20 May 2020.

Hartmann, H.T.; Kester, D.E.; Junior Davies, F.T.; Geneve, R.L. Plant propagation: principles and practices. New Jersey: Englewood Clipps, 2011. 900p.

Hernández, W.; Xavier, A.; Paiva, H.N.; Wendling, I. Propagação vegetativa do Jequitibá-Rosa (Cariniana estrellensis (Raddi) KUNTZE) por Estaquia. Revista Árvore, v.37, n.5, p.955-967, 2013. https://doi.org/10.1590/S0100-67622013000500018.

Kotz, T.E.; Pio, R., Chagas, E.A.; Campagnolo, M.A., Bettiol Neto, J.E., Tadeu, M.H. Época de coleta das estacas, do uso de fitorregulador de enraizamento e de diferentes tipos de enxertos na produção de mudas de figueira 'Roxo de Valinhos'. Semina: Ciências Agrárias, v.32, n.1, p.31-38, 2011. https://doi.org/10.5433/16790359.2011v32n1p31.

Kumar, V.V.N.; Prabhukumar, K.M.; Bhavadas, N.; Sunil, C.N.; Balachandran, I. Rediscovery of Phyllanthus macrocalyx Mull. Arg. (Phyllanthaceae), a rare endemic species of the Western Ghats, India. Current Science, v.110, n.1, 2016. https://doi. org/10.18520/cs/v110/i1/33-35.

Martins, S.V. Restauração ecológica de ecossistemas degradados. Viçosa: Editora UFV, 2015. 376p.

Monteiro, J.S.; Leite, M.B.; Wink, C.; Durlo, M.A. Influência do ângulo de plantio sobre a brotação e o enraizamento de estacas de Phyllanthus sellowianus (Klotzsch) Mull. Arg. Ciência Florestal, v.20, n.3, p.523-532, 2010. https://doi. org/10.5902/198050982066.

Moura, C.C. Propagação da Richeria grandis Vahl. (Phyllanthaceae). Diamantina: Universidade Federal dos Vales do Jequitinhonha e Mucuri, 2017. 91p. Dissertação Mestrado. http://acervo.ufvjm. edu.br/jspui/handle/1/1597. 13 May 2020.

Nogueira, A.M. Mata ciliar na proteção de fluxo de nutrientes em corpos hídricos lacustres. Alfenas: Universidade Federal de Alfenas, 2016. 88p. Dissertação Mestrado. https://bdtd.unifalmg.edu.br:8443/handle/tede/801. 03 May 2020. 
Oliveira, A.C.; Dorigon, E.B. Propagação vegetativa de Erva-mate (Ilex paraguariensis St. Hil.). Jornada Integrada em Biologia, v.3, p.75-82, 2016. https://portalperiodicos.unoesc.edu.br/ jornadaintegradaembiologia/article/view/10252. 10 May 2020.

Oliveira, L.C.S.; Guimarães, J.C.O.; Souza, I.C.S.; Lima, C.M.; Ferreira, W.C. Levantamento florístico e fitossociológico da regeneração natural de uma mata de galeria localizada no município de Jataí - GO. Global Science and Technology, v.8, n.3, p.59-77, 2015. https://doi.org/10.14688/1984-3801/gst.v8n3p59-77.

Oliveira, L.M.B. Sobrevivência e crescimento de mudas resgatadas em função do tempo de transplantio e níveis de sombreamento. Diamantina: Universidade Federal dos Vales do Jequitinhonha e Mucuri, 2014. 62p. Dissertação Mestrado. http://acervo.ufvjm. edu.br/jspui/handle/1/333. 10 May 2020.

Oliveira, M.C. Enraizamento de estacas de dez espécies arbóreas nativas de Matas de Galeria. Brasília: Universidade de Brasília, 2003. 125p. Dissertação Mestrado.

Oliveira, M.C.; Ribeiro, J.F. Enraizamento de estacas de Euplassa inaequalis (pohl) Engl. de mata de galeria em diferentes estações do ano. Bioscience Journal., v.29, n.4, p.991-999, 2013. http://www.seer.ufu.br/index.php/biosciencejournal/article/ view/15203. 20 May 2020.

R Development Core Team. R: A language and environment for statistical computing. R foundation for statistical computing, Vienna: Austria. R Version 4.0.0. 2020. http://www.r-project. org/. 18 May 2020.

Rabinowitz, D. Seven forms of rarity. In: Synge, H. (Org.). The biological aspects of rare plant conservation. New York: Wiley, 1981. p. 205-217.
Rezende, R.S.; Sales, M.A.; Hurbath, F.; Roque, N.; Gonçalvel Júnior, J.F.; Medeiros, A.O. Effect of plant richness on the dynamics of coarse particulate organic matter in a brazilian Savannah stream. Limnologica, v.63, p.57-64, 2017. https://doi.org/10.1016/j. limno.2017.02.002.

Rios, M.N.S.; Ribeiro, J.F. Enraizamento de estacas de cinco espécies de mata de galeria em diferentes épocas do ano. Enciclopédia Biosfera, v.10, n.18, p.1524-1536, 2014. http://www.conhecer.org. br/enciclop/2014a/AGRARIAS/Enraizamento.pdf. 20 May 2020.

Santin, D. Wendling, I.; Benedetti, E.L.; Morandi, D.; Domingos, D.M. Sobrevivência, crescimento e produtividade de plantas de erva-mate produzidas por miniestacas juvenis e por sementes. Ciência Florestal, v.25, n.3, p.571-579, 2015. https://doi. org/10.5902/1980509819608.

Silva, N.S.L.; Silva, N.O.; Schliewe, M.A.; Darosci, A.A.B. Desenvolvimento de plântulas em área degradada de mata de galeria no Parque Municipal Mata da Bica, Formosa-GO. RETEC, v. 8, n. 1, p. 17-35, 2015. https://www.fatecourinhos.edu.br/retec/ index.php/retec/article/view/184/125. 20 May 2020.

Silveira, S.S.; Cordeiro-Silva, R.; Degenhardt-Goldbach, J.; Quoirin, M.M. Micropropagation of Calophyllum brasiliense (Cambess.) from nodal segments. Brazilian Journal of Biology, v.76, n.3, p. 656-663, 2016. https://doi.org/10.1590/1519-6984.23714.Porto Alegre: Artmed, 2013. 918p.

Wyse, S.V.; Dickie, J.B. Predicting the global incidence of seed desiccation sensivity. Journal of Ecology, v.105, n.4, p. 1082-1093, 2017. https://doi.org/10.1111/1365-2745.12725.

Xavier, A.; Wendling, I.; Silva, R.L. Silvicultura clonal: princípios e técnicas. Viçosa: Editora UFV, 2013. 279p. 